\title{
The effect of forest age and habitat structure on the ground-dwelling ant assemblages of lowland poplar plantations
}

\author{
Róbert Gallé, Attila Torma and István Maák \\ Department of Ecology, University of Szeged, H-6726 Szeged, Hungary
}

\begin{abstract}
Intensive management causes significant changes to the habitat structure of forest stands and threatens forest specialist insect species. To assess and counteract the effect of periodic intensive forestry interventions, such as clear-cutting and reforestation, it is important to adequately quantify the recovery rate and composition of the native biota. We aimed to characterize the above parameters for ant assemblages in forests with different structure and age.

2 Epigeic ant assemblages were studied using pitfall traps in young (6-10 years old), middle-aged (23-26 years old) and mature (35-37 years old) poplar forest plantations in the Kiskunság region of Hungary.

3 Species richness of ant assemblages and the abundance of nonforest ants did not differ among the age classes. The abundance of forest specialist ants was, however, higher in middle-aged and mature stands compared with young plantations. The assemblage composition of ants significantly correlated with habitat structure and forest age.

4 We conclude that nonforest ant species can persist throughout the entire forestry cycle in poplar plantations with moderate tree density. The present study suggests that forest age and habitat structure together shape the ant assemblages of lowland poplar plantations.
\end{abstract}

Keywords Clear-cut, forest management, forestry cycle, Kiskunság.

\section{Introduction}

During the last century, the intensification of forestry practices has resulted in significant ecological changes in Central European forests (Oxbrough et al., 2014). The species composition of forests has shifted towards non-native tree species and the habitat structure has been homogenized and simplified (Paillet et al., 2010). Intensive forestry management induces changes in the composition of plant and invertebrate species, usually by reducing microhabitat diversity, which in turn reduces the number of species, especially the number of habitat specialists (Okland et al., 2003; Klimes et al., 2012).

The recovery of ground-dwelling forest-specific assemblages in the reforested habitats may depend on the dispersal ability of the species. Previous studies indicate that the number of invertebrate species increases at clear-cut forest sites because of the influx of generalist and open habitat species (Riley \& Browne, 2011; Magura etal., 2015). These species have been reported to occur at reforested sites until the forest canopy closes

Correspondence: Róbert Gallé. Tel.: +36702477838; e-mail: galle.robert@gmail.com
(Niemelä et al., 1996; Koivula et al., 2002). Active species can colonize young forests easily and establish viable populations (Magura et al., 2015). Proximity to undisturbed mature forests may also increase the recolonization success of forest invertebrates in areas influenced by harvesting or natural disturbance (Baker et al., 2013).

Ants are a diverse and locally very abundant group of omnivorous forest arthropods. Biotic interactions, particularly competition, play an important role in shaping their assemblages (Cerdá et al., 1998; Chong etal., 2011). Abundant and behaviourally dominant species can affect the species richness and the distribution of other ants in the assemblage because they can monopolize concentrated food sources and reduce the number of other ant species within their foraging area (Parr \& Gibb, 2010; Baccaro et al., 2012). Dominant ant species can also reduce the abundance of other ground-dwelling invertebrates via direct predation or interference competition (Mestre et al., 2012; Hawes et al., 2013). However, numerous studies emphasize that habitat structure is also important in determining the structure of ant communities (Gallé, 1991, 1999; Alvarado, 2000; Arnan et al., 2009; Gibb, 2011). 
The present study analyses the effects of habitat parameters and forest age on the diversity and composition of ground dwelling ant assemblages in a forest-rich landscape in Southern Hungary. We hypothesized that forest age and habitat structure have an effect on the species richness and species composition of ant assemblages. We expected a higher abundance of good-colonizer and generalist species in the younger forests, whereas forest specialists (i.e. behaviourally dominant red-wood ants) are expected to occur mainly in the middle-aged and older forests.

\section{Materials and methods}

\section{Study sites and sampling}

The present study was carried out in the southern part of the Hungarian Great Plain. As result of the intensive management, the forests of the region consist of stands with various age, structure and composition. The most widespread tree species include the non-native black locust (Robinia pseudoacacia), pines (Pinus spp.) and the native silver poplar (Populus alba). We established 15 study sites near Bugacpusztaháza village (approximately $46^{\circ} 42^{\prime} \mathrm{N}, 19^{\circ} 36^{\prime}$; see Supporting information, Appendix S1). The study sites were poplar forest plantations where less than $25 \%$ of the trees were black locusts. We used a space-for-time substitution procedure to represent the consecutive stages of the forestry cycle. After clear-cuttings, mechanical soil treatment is applied in the region, resulting in bare soil surfaces. Newly established plantations (i.e. less than 6 years old) were excluded from the study because airborne sand precluded the pitfall trap sampling of ground-dwelling fauna. Three stages were sampled. (i) Young plantations, aged between 6 and 10 years. The canopy closure was almost complete, and the shrub and herb layers were sparse with a very low cover of native dicots (mean \pm SD: $2.65 \pm 2.07 \%$ ). By contrast, the cover of the invasive plant Asclepias syriaca was high at young plantations (mean \pm SD: $15.5 \pm 9.25 \%$ ). (ii) Middle-aged stands 23-26-year-old stands. The closure of the canopy was complete, and the shrub layer was denser compared with other age classes. (iii) Mature forests before clear-cut harvesting; aged 35-37 years. The highest amount of woody debris was found in this stage; therefore, the conditions for nest building was presumably the best in this age group.

The size of the plantations did not differ between age classes (young plantations: $7.08 \pm 5.55$ ha, middle-aged stands: $7.70 \pm 5.77$ ha, old forests: $11.52 \pm 5.82 \mathrm{ha}$; one-way analysis of variance, $F=0.881, P=0.449$ ).

The surrounding landscape mainly consisted of different aged forests $(66.7 \pm 20.6 \%)$ closed canopy forests in a $500-m$ buffer around the sampling sites, agricultural fields and pastures (Gallé et al., 2014a). To sample the forest floor ant fauna, pitfall traps were used. Ten traps were installed at each site and were placed $5 \mathrm{~m}$ apart. The pitfall trap method does not give an exact density estimate; rather, it assesses the activity density of ants. However, several studies have demonstrated that the pitfall trap method is a relatively good tool for comparing the assemblage structure of ants because the cruising radius of workers can reach $150 \mathrm{~m}$ around their usually fixed nests (Andersen, 1991; Schlick-Steiner et al., 2006; Underwood \& Fisher, 2006; Gotelli et al., 2011). Hand-sampling is more efficient than pitfall traps because it usually yields more species and direct estimates of nest densities; however, hand-sampling can be affected by the expertise of the collector and vegetation structure of the sampled habitat. In the case of the present study, the structure of the understory vegetation and the amount of woody debris were different; thus, we used the pitfall trap method exclusively. The data of the pitfall traps were pooled prior to data analyses. To minimize the confounding effect of edges, traps were placed at least $50 \mathrm{~m}$ from the edge of the studied forest stand because Larrivée et al. (2008) found that ground-dwelling invertebrates of adjacent habitats do not penetrate this far into the forest interior. We used plastic jars as traps $(6.5 \mathrm{~cm}$ in diameter), filled them up to one-third with a $70 \%$ ethylene glycol dissolved in water and added a few drops of an odourless detergent (Koivula et al., 2003; Schmidt et al., 2006). A plastic roof was placed above each trap to prevent dilution of the preservative solution by rain. Trapping was conducted continuously between 19 May and 20 June 2012 (32 days).

To characterize habitat structure, the percentage cover of leaf litter, understory vegetation and the average height of the herbaceous vegetation were recorded within four $1 \times 1 \mathrm{~m}$ quadrats at each site. The photographs were analyzed in the laboratory by visually assessing the proportion of leaves. The decaying woody material was collected and measured after the invertebrate sampling. We measured the cumulative length of fine (diameter $<8 \mathrm{~cm}$ ) and coarse (diameter $8-15 \mathrm{~cm}$ ) woody debris and recorded the presence of bigger trunks (diameter $>15 \mathrm{~cm}$ ) in four $2 \times 2 \mathrm{~m}$ quadrats at each site. We did not find significant correlations between the habitat parameters (see Supporting information, Appendix S2).

We identified ants using the keys of Seifert (2007) and Czechowski etal. (2012). Nomenclature follows Czechowski etal. (2012).

\section{Statistical analysis}

Characteristic ant species of the forestry cycle stages were identified by the IndVal (Indicator Value) calculation on the basis of the relative frequency and relative average abundance of the species in the samples (Dufrêne \& Legendre, 1997). The statistical significance of the species indicator values was evaluated by a Monte Carlo procedure.

The effect of forest stage and habitat parameters on ant species richness were tested with general linear models (GLM) with poisson error term and log-link function, followed by stepwise model selection procedure on the basis of Akaike's information criterion. We allocated habitat requirements to ant species on the basis of Czechowski et al. (2012); the categories that we used were the forest specialists and nonforest species (species with no prevalence in forests). The effects of forest stage and habitat structure on the amount of ants belonging to the above categories were tested with GLMs with a negative binomial error term because of the overdispersion of the data.

The multivariate response of assemblages to forest stage and habitat structure was studied with constrained ordination. A preliminary detrended correspondence analysis was conducted to gain insight into how the species respond to the environmental gradient. The gradient length was 2.17 and did not exceed 4.0 , indicating a linear response of the species variance to 
the environmental gradient. We performed a linear redundancy analysis. To identify the parameters that explain a significant proportion of the variation, we performed a stepwise model selection procedure (ordistep function in the Vegan package in $\mathrm{R}$; $\mathrm{R}$ Foundation for Statistical Computing, Austria). The marginal effects of the variables were calculated and tested by Monte Carlo permutation tests with 5000 permutations.

Similarity patterns in species composition and assemblage structure between the sampling sites were explored using non-metric multidimensional scaling (NMDS) based on Bray-Curtis distance matrix. To visualize their effect, the significant environmental variables of the redundancy analysis were fitted passively onto the NMDS ordination plot.

\section{Results}

We collected 13147 ant individuals from 22 species (see Supporting information, Appendix S3). This included 2006 individuals of 17 species in the young plantations, 5933 individuals of 18 species in the middle-aged stands and 5208 individuals of 18 species in the mature plantations. The most common ant species was Formica (Serviformica) fusca Linnaeus 1758, representing 6258 individuals. This very common opportunistic ant species is at the lowest level of the interspecific competition hierarchy (Czechowski et al., 2012). Two Lasius species, Lasius paralienus (Seifert, 1992) and Lasius niger (Linnaeus, 1758), were also abundant. These widespread species are not forest species but were found in most of the sampling sites. Members of the Formica rufa group are the top dominant species in the interspecific competition hierarchy of forest assemblages (Pisarski \& Vepsäläinen, 1989). Five species, but only 197 specimens, of these territorial mound-building ants were collected.

Three significant indicator species were identified with the indicator value procedure: Tetramorium caespitum (Linnaeus, 1758) for young stands (IndVal $=0.792, P=0.015$ ), and Temnothorax crassispinus (Karavaiev, 1926) (IndVal $=0.718$, $P=0.031)$ and Temnothorax unifasciatus (Latreille, 1798) (IndVal $=0.607, P=0.010$ ) for mature plantations.

We found no significant model for the species richness of ant assemblages; however, in accordance with our hypothesis, the abundance of forest specialist species was lower in the young plantation than in the middle-aged plantations $(Z=5.114, \quad P<0.001, \quad n=15)$ and the old forest stands $(Z=7.799, P<0.001, n=15)$. The presence of tree trunks $(Z=-2.190, \quad P=0.028, n=15)$ and the vegetation cover $(Z=-3.492, P<0.001, n=15)$ also influenced the abundance of forest ants according to the GLMs. The structural parameters influenced the abundance of nonforest ants as well (presence of tree trunks: $Z=-4.790, P<0.001, n=15$; vegetation cover: $Z=2.929, P=0.003, n=15$; average height of the herbaceous vegetation: $Z=-3.343, P<0.001, n=15)$, although forest age had no detectable effect on them.

The results of the significant redundancy analysis model showed that the age of the forests $(F=5.825, P=0.004, N=15)$, the cumulative length of fine $(F=4.021, P=0.040, N=15)$ and coarse $(F=7.176, P=0.008, N=15)$ woody debris had a significant role in shaping the composition of the studied ant assemblages (Fig. 1).

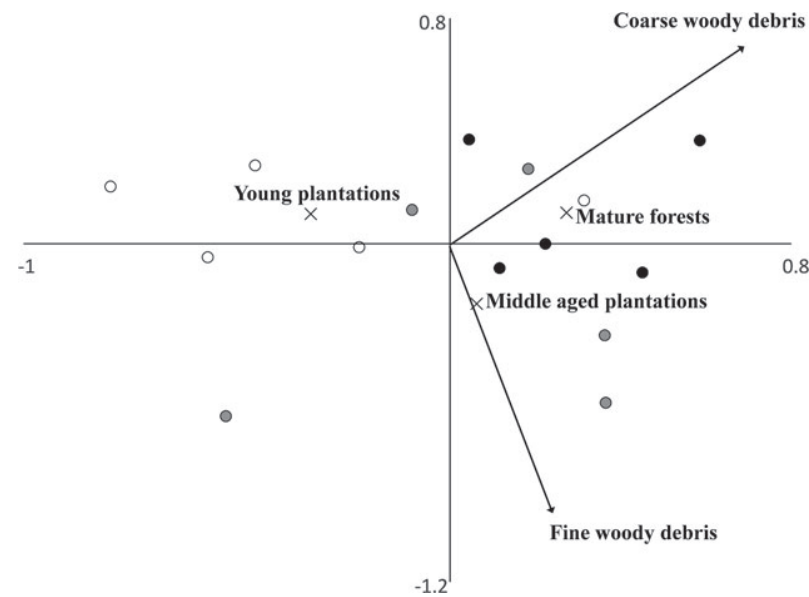

Figure 1 The result of the non-metric multidimensional scaling model. The symbols indicate the age of the forests. Open circles, young plantations; grey circles, middle-aged plantations; black circles, mature plantations. The significant parameters of the redundancy analysis models are fitted passively onto the diagram. The crosses represent the age classes of the plantations.

\section{Discussion}

The present study, in line with our hypothesis, showed that both forest age and habitat structure significantly influenced the ant assemblages. The effect was different for forest specialist species and for nonforest species; forest age was significant for forest species, although we did not find differences in nonforest ant abundances among the forest stages.

The indicator species analysis (IndVal procedure) showed that one ant species, T. caespitum, was specific to young plantations, whereas other species were typical of mature stands. Tetramorium caespitum is a semixerophilous species and it is common on dry sandy soils with sparse vegetation. This species defends food resources and nests (Cerdá et al., 2009) and T. caespitum is at the high level of the dominance hierarchy in young plantations as a result of the low abundance of red wood ants. The analysis also showed that $T$. crassispinus and T. unifasciatus were characteristic of mature stands, confirming that both species have a strong affinity to forest habitats (Czechowski et al., 2012).

Numerous studies have documented significant changes in invertebrate assemblages after clear-cutting (Koivula, 2011; Magura etal., 2015). Forestry practices and soil preparation destroy microhabitats required by forest specialist species, causing the disappearance of most of these species from young stands (Magura et al., 2003). A rapid initial colonization of generalist and open habitat specialist invertebrates takes place after the disturbance of the habitat (Bröring \& Wiegleb, 2005; Gallé et al., 2014a). Besides generalist and open habitat species with good colonizing abilities, some forest specialist species can also persist, which results in an increased abundance or diversity in young forest stands (Koivula et al., 2002). Several studies have reported that forest ant assemblages change dramatically within 2 years after clear-cutting (Sorvari \& Hakkarainen, 2005; Neuvonen et al., 2012); old-growth forest specialists almost disappear, presumably because of the loss of arboreal food resources (Punttila etal., 1991), although Gibb and Johansson (2010) 
found that ant workers collected similar amounts of hemipteran honeydew from recently clear-cut sites and the different aged forest stands, suggesting an optimization of foraging effort.

In the present study, we also found that forest age had an effect on the species composition of ant assemblages but that species richness did not differ among forest age classes. We did not find a higher diversity of ants in the young stands and forest age did not have a significant effect on the abundance of nonforest ants. The change in species composition was presumably a result of the colonization by forest ant species.

Regional species pool and landscape structure are also important factors in shaping local diversity. The species composition of invertebrates in recently clear-cut habitats is strongly affected by the presence of the source populations of the potential colonizers (Koivula, 2011); thus, the surrounding matrix and landscape composition have a pronounced effect on recently established habitats. In the present study, the surrounding landscape mainly consisted of different aged forests with various species composition; thus, the source populations of forest specialist species were undoubtedly present in the surrounding landscape.

In accordance with our results, several studies emphasize that the species composition of ant assemblages also responds to structural changes of the habitats (Bestelmeyer \& Wiens, 1996; Lubertazzi \& Tschinkel, 2003; Lassau \& Hochuli, 2004). Several environmental conditions probably change in parallel to changes in the herbaceous vegetation and canopy closure; differences in ground-shading and plant transpiration can create temperature, soil and humidity gradients (Lubertazzi \& Tschinkel, 2003). The increasing numbers of fallen and decaying branches can serve as suitable nesting sites for ants (Alvarado, 2000), especially for F. fusca, which is the most abundant ant species in the present study.

In general, only a small number of ant species are able to live in closed forests (Holec \& Frouz, 2005). Only eight of the collected species were forest specialists, and the abundance of forest ants was lower in the young plantations than in the middle-aged and mature stands. Poplar forests have a relatively open canopy compared with non-native plantations (Gallé et al., 2014b). Generalist and open habitat specialist ant species also occurred in the sampled poplar forests: in the present study, 14 of the 22 species collected had no pronounced prevalence in forests. Other studies emphasize a consistent pattern of insect species composition change in the early stages of the forestry cycle. After canopy closure, the number and abundance of generalist and open habitat species decline (Buddle et al., 2006; Taboada et al., 2008; Oxbrough et al., 2010). However, most studies have been conducted in situations where the mature forests have a closed canopy (e.g. conifer plantations). Our analysis did not show significant differences in the abundance of nonforest species among forest age classes, indicating that, in forest stands with a relatively open tree canopy, these species also persist in later stages of the forestry cycle.

Interference competition has an increasing significance in advanced successional stages (Gallé et al., 1998; Gibb, 2011). In the later stages of succession, changes in habitat properties and the appearance of dominant, aggressive species can lead to the exclusion of early colonizing ant species (Vepsäläinen et al., 2000). Besides foraging on the forest floor, redwood ants also forage efficiently on tree trunks (Lenoir, 2002; Neuvonen et al.,
2012) and, in the present study, there was a low abundance of the $F$. rufa group, which might be explained by a weak effect of interference competition in shaping assemblage composition of the forest stands studied.

The present study confirmed the correlation between habitat structure, forest age and ground-dwelling ant assemblages. Besides the forest specialist ants, most generalist species meet their habitat requirements in mature stands. Our results also suggest that the abundance of dominant ants has little effect on the number of species in these ant assemblages, and that forest age is probably more important than interference competition in the case of lowland poplar plantations.

\section{Acknowledgements}

We wish to thank the anonymous reviewers for reading the early version of the manuscript and making valuable comments. We are grateful to Csaba Tölgyesi and László Gallé for providing advice on a previous version of the manuscript. We also thank Judit Kovács, Anna Somogyi, Szabina Schwéger, Nikolett Szpisjak and Tünde Csorba for their help with the fieldwork and for sorting the collected material.

\section{Supporting information}

Additional Supporting information may be found in the online version of this article under the DOI reference:

10.1111/afe. 12148

Appendix S1. The location of the study sites.

Appendix S2. Spearman correlation matrix of numeric habitat parameters.

Appendix S3. The list of the collected species and habitat requirements. F, forest specialist; Non-F, non-forest species.

\section{References}

Alvarado, M. (2000) Habitat correlates of ant assemblages in different forests of the South Pannonian Plain. Tiscia, 32, 35-42.

Andersen, A.N. (1991) Sampling communities of ground-foraging ants: pitfall catches compared with quadrat counts in an Australian tropical savanna. Australian Journal of Ecology, 16, 273-279.

Arnan, X., Gracia, M., Comas, L. \& Retana, J. (2009) Forest management conditioning ground ant community structure and composition in temperate conifer forests in the Pyrenees Mountains. Forest Ecology and Management, 258, 51-59.

Baccaro, F.B., De Souza, J.L.P., Franklin, E., Lemes Landeiro, V. \& Magnusson, W.E. (2012) Limited effects of dominant ants on assemblage species richness in three Amazon forests. Ecological Entomology, 37, 1-12.

Baker, S.C., Spies, T.A., Wardlaw, T.J., Balmer, J., Franklin, J.F. \& Jordan, G.J. (2013) The harvested side of edges: effect of retained forests on the re-establishment of biodiversity in adjacent harvested areas. Forest Ecology and Management, 302, 107-121.

Bestelmeyer, B.T. \& Wiens, J.A. (1996) The effects of land use on the structure of ground-foraging ant communities in the Argentine Chaco. Ecological Monographs, 6, 1225-1240.

Bröring, U. \& Wiegleb, G. (2005) Soil zoology II: colonization, distribution, and abundance of terrestrial Heteroptera in open landscapes 
of former brown coal mining areas. Ecological Engineering, 24, 135-147.

Buddle, C.M., Langor, D.W., Pohl, G.R. \& Spence, J.R. (2006) Arthropod responses to harvesting and wildfire: implications for emulation of natural disturbance in forest management. Biological Conservation, 128, 346-357.

Cerdá, X., Retana, J. \& Manzaneda, A. (1998) The role of competition by dominants and temperature in the foraging of subordinate species in Mediterranean ant communities. Oecologia, 117, 404-412.

Cerdá, X., Palacios, R. \& Retana, J. (2009) Ant community structure in citrus orchards in the Mediterranean Basin: impoverishment as a consequence of habitat homogeneity. Environmental Entomology, 38, 317-324.

Chong, C.S., Hoffmann, A.A. \& Thomson, L.J. (2011) Local-scale spatial dynamics of ants in a temperate agroecosystem. Austral Ecology, 36, 413-424.

Czechowski, W., Radchenko, A., Czechowska, W. \& Vepsäläinen, K. (2012) The Ants of Poland with Reference to the Myrmecofauna of Europe. Natura optima dux Foundation, Poland.

Dufrêne, M. \& Legendre, P. (1997) Species assemblages and indicator species: the need for a flexible asymmetrical approach. Ecological Monographs, 67, 345-366.

Gallé, L. (1991) Structure and succession of ant assemblages in a north European sand dune area. Ecography, 14, 31-37.

Gallé, L. (1999) Composition and structure of primary successional sand-dune ant assemblages: a continental-scale comparison. Soil Zoology in Central Europe (ed. by K. Tajovsky and V. Pizl), pp. 67-74. ISB AS CR, Czech Republic.

Gallé, L., Körmöczi, L., Hornung, E. \& Kerekes, J. (1998) Structure of ant assemblages in a Middle-European successional sand-dune area. Tiscia, 31, 19-28

Gallé, R., Maák, I. \& Szpisjak, N. (2014a) The effects of habitat parameters and forest age on the ground dwelling spiders of lowland poplar forests (Hungary). Journal of Insect Conservation, 18, 791-799.

Gallé, R., Kanizsai, O., Ács, V. \& Molnár, B. (2014b) Functioning of ecotones - spiders and ants of edges between native and non-native forest plantations. Polish Journal of Ecology, 62, 815-820.

Gibb, H. (2011) Experimental evidence for mediation of competition by habitat succession. Ecology, 92, 1871-1878.

Gibb, H. \& Johansson, T. (2010) Forest succession and harvesting of hemipteran honeydew by boreal ants. Annales Zoologici Fennici, 47, 99-110.

Gotelli, N.J., Ellison, A.M., Dunn, R.R. \& Sanders, N.J. (2011) Counting ants (Hymenoptera: Formicidae): biodiversity sampling and statistical analysis for myrmecologists. Myrmecological News, 15, 13-19.

Hawes, C., Evans, H.F. \& Stewart, A.J. (2013) Interference competition, not predation, explains the negative association between wood ants (Formica rufa) and abundance of ground beetles (Coleoptera: Carabidae). Ecological Entomology, 38, 315-322.

Holec, M. \& Frouz, J. (2005) Ant (Hymenoptera: Formicidae) communities in reclaimed and unreclaimed brown coal mining spoil dumps in the Czech Republic. Pedobiologia, 49, 345-357.

Klimes, P., Idigel, C., Rimandai, M., Fayle, T.M., Janda, M., Weiblen, G.D. \& Novotny, V. (2012) Why are there more arboreal ant species in primary than secondary tropical forests? Journal of Animal Ecology, 81, 1103-1112.

Koivula, M. (2011) Useful model organisms, indicators, or both? Ground beetles (Coleoptera, Carabidae) reflecting environmental conditions. ZooKeys, 100, 287-317.

Koivula, M., Kukkonen, J. \& Niemelä, J. (2002) Boreal carabid beetle (Coleoptera, Carabidae) assemblages along the clear-cut originated succession gradient. Biodiversity and Conservation, 11, $1269-1288$
Koivula, M., Kotze, D.J., Hiisivuori, L. \& Rita, H. (2003) Pitfall trap efficiency: do trap size, collecting fluid and vegetation structure matter? Entomologica Fennica, 14, 1-14.

Larrivée, M., Drapeau, P. \& Fahrig, L. (2008) Edge effects created by wildfire and clear-cutting on boreal forest ground-dwelling spiders. Forest Ecology and Management, 255, 1434-1445.

Lassau, S.A. \& Hochuli, D.F. (2004) Effects of habitat complexity on ant assemblages. Ecography, 27, 157-164.

Lenoir, L. (2002) Can wood ants distinguish between good and bad patches on the forest floor? European Journal of Soil Biology, 38, 97-102.

Lubertazzi, D. \& Tschinkel, W.R. (2003) Ant community change across a ground vegetation gradient in north Florida's longleaf pine flatwoods. Journal of Insect Science, 3, 21.

Magura, T., Tóthmérész, B. \& Elek, Z. (2003) Diversity and composition of carabids during a forestry cycle. Biodiversity and Conservation, 12, $73-85$.

Magura, T., Bogyó, D., Mizser, S., Nagy, D.D. \& Tóthmérész, B. (2015) Recovery of ground-dwelling assemblages during reforestation with native oak depends on the mobility and feeding habits of the species. Forest Ecology and Management, 339, 117-126.

Mestre, L., Piñol, J., Barrientos, J.A., Cama, A. \& Espadaler, X. (2012) Effects of ant competition and bird predation on the spider assemblage of a citrus grove. Basic and Applied Ecology, 13, 355-362.

Neuvonen, S., Saikkonen, T., Sundström, L. et al. (2012) Stand type is more important than red wood ant abundance for the structure of ground-dwelling arthropod assemblages in managed boreal forests. Agricultural and Forest Entomology, 14, 295-305.

Niemelä, J.K., Haila, Y. \& Punttila, P. (1996) The importance of small-scale heterogeneity in boreal forests: variation in diversity of forest floor invertebrates across the succession gradient. Ecography, 19, 352-368.

Okland, T.K., Rydgren, R.H., Okland, K.O., Storaunet, J. \& Rolstad, J. (2003) Variation in environmental conditions, understorey species number, abundance and composition among natural and managed Picea abies forest stands. Forest Ecology and Management, 177, 17-37.

Oxbrough, A., Irwin, S., Kelly, T.C. \& O'Halloran, J. (2010) Ground dwelling invertebrates in reforested conifer plantations. Forest Ecology and Management, 259, 2111-2121.

Oxbrough, A., Irwin, S., Wilson, M. \& O'Halloran, J. (2014) Mechanisms and predictors of ecological change in managed forests: a selection of papers from the second international conference on biodiversity in forest ecosystems and landscapes. Forest Ecology and Management, 321, $1-4$.

Paillet, Y., Bergès, L., Hjältén, J., Ódor, P. et al. (2010) Biodiversity differences between managed and unmanaged forests: meta-analysis of species richness in Europe. Conservation Biology, 24, 101-112.

Parr, C.L. \& Gibb, H. (2010) Competition and the role of dominant ants. Ant Ecology (ed. by L. Lach, C. L. Parr and K. L. Abbott), pp. 77-96. Oxford University Press, New York, New York.

Pisarski, B. \& Vepsäläinen, K. (1989) Competitive hierarchy in ant communities (Hymenoptera, Formicidae). Annales Zoologici, 42, 321-329.

Punttila, P., Haila, Y., Pajunen, T. \& Tukia, H. (1991) Colonisation of clearcut forests by ants in the southern Finnish taiga: a quantitative survey. Oikos, 61, 250-262.

Riley, K.N. \& Browne, R.A. (2011) Changes in ground beetle diversity and community composition in age structured forests (Coleoptera, Carabidae). ZooKeys, 147, 601-621.

Schlick-Steiner, B.C., Steiner, F.M., Moder, K., Bruckner, A., Fiedler, K. \& Christian, E. (2006) Assessing ant assemblages: pitfall trapping versus nest counting (Hymenoptera, Formicidae). Insectes Sociaux, 53, 274-281. 
Schmidt, M.H., Clough, Y., Schulz, W., Westphalen, A. \& Tscharntke, T. (2006) Capture efficiency and preservation attributes of different fluids in pitfall traps. Journal of Arachnology, 34, 159-162.

Seifert, B. (2007) Die Ameisen Mittel- und Nordeuropas. Lutra-Verlags-und Vertriebsgesellschaft, Germany.

Sorvari, J. \& Hakkarainen, H. (2005) Deforestation reduces nest mound size and decreases the production of sexual offspring in the wood ant Formica aquilonia. Annales Zoologici Fennici, 42, 259-267.

Taboada, A.D., Kotze, J., Tárrega, R. \& Salgado, J.M. (2008) Carabids of differently aged reforested pinewoods and a natural pine forest in a historically modified landscape. Basic and Applied Ecology, 9, $161-171$.

Underwood, E.C. \& Fisher, B.L. (2006) The role of ants in conservation monitoring: if, when, and how. Biological Conservation, 132, 166-182.

Vepsäläinen, K., Savolainen, R., Tiainen, J. \& Vilén, J. (2000) Successional changes of ant assemblages: from virgin and ditched bogs to forests. Annales Zoologici Fennici, 37, 135-149.

Accepted 19 January 2016 